\title{
Enzymatic Reduction of Hexavalent Chromium by Hexavalent Chromium Tolerant Pseudomonas ambigua G-1
}

\author{
Hiroyuki Horitsu, Satoshi Futo, Yoshimi Miyazawa, \\ Shusuke OGaI and Keiichi KawaI \\ Department of Agricultural Chemistry, Faculty of Agriculture, \\ Gifu University, Yanagido, Gifu 501-11, Japan
}

Received March 23, 1987

\begin{abstract}
When hexavalent chromium $\left(\mathrm{Cr}^{6+}\right)$ tolerant Pseudomonas ambigua G-1 was cultivated in nutrient broth containing $150 \mathrm{ppm} \mathrm{Cr}^{6+}$, the $\mathrm{Cr}^{6+}$ content of the broth rapidly decreased. The $\mathrm{Cr}^{6+}$ reducing enzyme found in a cell-free extract of $P$. ambigua G-1 required NADH but not NADPH as a hydrogen donor for the reduction of $\mathrm{Cr}^{6+}$. The specific activities of cell-free extracts of several $\mathrm{Cr}^{6+}$ sensitive mutants derived from P. ambigua G-1 showed decreases to one fourth to one tenth of that of $P$. ambigua $\mathrm{G}-1$. Glucose protected the $\mathrm{Cr}^{6+}$ reducing enzyme against inactivation on dialysis.
\end{abstract}

Although chromium $(\mathrm{Cr})$ is known to be essential for the growth of microorganisms, a high concentration of $\mathrm{Cr}$ is toxic for many bacteria. Of the two stable $\mathrm{Cr}$ forms as to valency, hexavalent $\mathrm{Cr}\left(\mathrm{Cr}^{6+}\right)$ is more toxic than the trivalent form $\left(\mathrm{Cr}^{3+}\right)$. Many kinds of bacteria have been isolated which are able to grow on a medium containing a high concentration of $\mathrm{Cr}^{6+} \cdot{ }^{15}$ ) The mechanisms of tolerance to $\mathrm{Cr}^{6+}$ of bacteria have not been yet sufficiently studied. $\mathrm{Cr}^{6+}$ can be reduced through an indirect microbial process in marine environments. ${ }^{6)}$

We reported previously that $\mathrm{Cr}^{6+}$ tolerant Pseudomonas ambigua G-1 had a thick envelope which prevented the permeation of $\mathrm{Cr}^{6+}$ into the cells. ${ }^{7)}$

In this paper, we describe another mechanism of $\mathrm{Cr}^{6+}$ tolerance in this bacterum, that is, the direct reduction of $\mathrm{Cr}^{6+}$ to $\mathrm{Cr}^{3+}$ by a cell-free extract of $P$. ambigua $\mathrm{G}-1$.

\section{MATERIALS AND METHODS}

Materials. Potassium chromate $\left(\mathrm{K}_{2} \mathrm{CrO}_{4}\right)$ was used as a hexavalent chromium. NAD-Linked yeast alcohol dehydrogenase and NADH were the products of Oriental Yeast Co., Ltd. NADPH was from Sigma Chemical Co.
Microorganism and growth conditions. P. ambigua G-1 was used throughout this study. The bacterium was isolated from activated sludge and tolerant to $4,000 \mathrm{ppm}$ $\mathrm{Cr}^{6+}$. The cells were cultivated aerobically in nutrient broth containing $150 \mathrm{ppm}^{6+}$.

Preparation of a cell-free extract. Cells harvested at the late $\log$ phase were washed three times with $10 \mathrm{~mm}$ Tris- $\mathrm{HCl}$ buffer ( $\mathrm{pH} 7.5$ ). The washed cells, suspended in the same buffer, were subjected to ultrasonic oscillation $(20 \mathrm{kHz})$ for five intervals of $10 \mathrm{~min}$ each, i.e., for a total $50 \mathrm{~min}$, under ice-cooling. The clear supernatant obtained on centrifugation at $15,000 \times g$ for $20 \mathrm{~min}$ was used as a cell-free extract.

Enzyme assay. $\mathrm{Cr}^{6+}$ reducing activity was assayed by measuring the decrease in $\mathrm{Cr}^{6+}$. The reaction mixture contained $0.4 \mu \mathrm{mol}$ of $\mathrm{K}_{2} \mathrm{CrO}_{4}, 0.4 \mu \mathrm{mol}$ of $\mathrm{NADH}$ and a suitable amount of the enzyme solution in $2.0 \mathrm{ml}$ of $10 \mathrm{~mm}$ phosphate buffer ( $\mathrm{pH}$ 7.0). The reactions were started by the addition of the enzyme solution. After incubation for $30 \mathrm{~min}$ at $50^{\circ} \mathrm{C}$, the reactions were stopped by heating for $2 \mathrm{~min}$ at $100^{\circ} \mathrm{C}$. The denatured proteins were centrifuged off. Residual $\mathrm{Cr}^{6+}$ in the reaction mixture was determined. One unit of $\mathrm{Cr}^{6+}$ reducing activity was defined as the amount of enzyme which catalyzed the decrease of one $\mu \mathrm{mol}$ of $\mathrm{Cr}^{6+}$ per $30 \mathrm{~min}$ at $50^{\circ} \mathrm{C}$.

Determination of total $\mathrm{Cr}$ and $\mathrm{Cr}^{6+}$. Total $\mathrm{Cr}$ was measured by the atomic adsorption method using a Hitachi Atomic Adsorption Spectrophotometer type 17040. $\mathrm{Cr}^{6+}$ was measured spectrophotometrically using diphenylcarbazide. $^{8)}$ 
Protein assay. The protein content was determined by the method of Folin and Ciocalteu ${ }^{9)}$ with egg white lysozyme as a standard.

\section{RESULTS}

Decrease in $\mathrm{Cr}^{6+}$ during cultivation of $P$. ambigua $G-1$

The time course of the $\mathrm{Cr}^{6+}$ decrease with $P$. ambigua G-1 is shown in Fig. $1 . \mathrm{Cr}^{6+}$ decreased rapidly during the early phase of growth. There was no decrease in total $\mathrm{Cr}$ in the culture medium. Although total $\mathrm{Cr}$ incorporated into the cell mass gradually increased as the cells grew, only $0.35 \mathrm{mg}$ of total $\mathrm{Cr}$ was incorporated into $155 \mathrm{mg}$ dry cells per $100 \mathrm{ml}$ of broth after $36 \mathrm{hr}$ cultivation. No decrease in $\mathrm{Cr}^{6+}$ occurred in the absence of the bacterium. These results indicate that $P$. ambigua $\mathrm{G}-1$ was able to change $\mathrm{Cr}^{6+}$ to another form as to valency of $\mathrm{Cr}$.

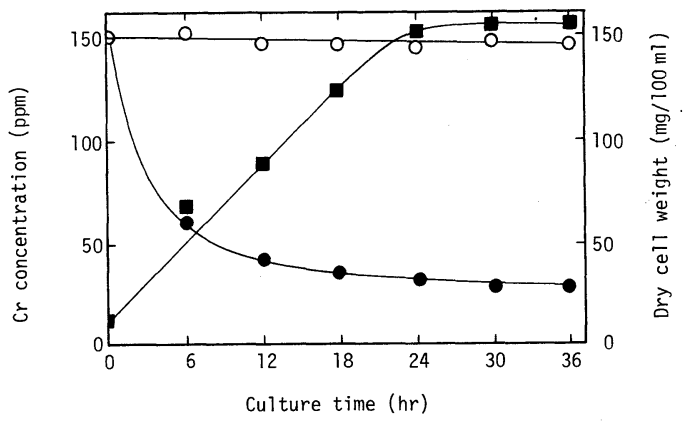

FIG. 1. Time Course of the $\mathrm{Cr}^{6+}$ Decrease with $\mathrm{Cr}^{6+}$ Tolerant P. ambigua G-1.

$\bigcirc$, total $\mathrm{Cr}$ in medium; $\mathbf{O}, \mathrm{Cr}^{6+}$ in medium; $\mathbf{\square}$, dry cell weight.

TABle I. Decrease in $\mathrm{Cr}^{6+}$ With a CELl-Free Extract

The reaction mixtures $(2.0 \mathrm{ml})$ contained $0.4 \mu \mathrm{mol}$ of $\mathrm{Cr}^{6+}, 1.6 \mathrm{ml}$ of a cell-free extract $(100 \mathrm{mg}$ protein) and $100 \mu \mathrm{mol}$ of potassium phosphate buffer (pH 7.0). The reactions were carried out at $50^{\circ} \mathrm{C}$.

\begin{tabular}{ccc}
\hline $\begin{array}{c}\text { Reaction } \\
\text { time (min) }\end{array}$ & $\begin{array}{c}\text { Total } \\
\mathrm{Cr}(\mu \mathrm{M})\end{array}$ & $\begin{array}{c}\mathrm{Cr}^{6+} \\
(\mu \mathrm{M})\end{array}$ \\
\hline 0 & 200 & 200 \\
30 & 198 & 120 \\
\hline
\end{tabular}

Decrease in $\mathrm{Cr}^{6+}$ with a cell-free extract of $\mathrm{P}$. ambigua $G-1$

To clarify the mechanism of the $\mathrm{Cr}^{6+}$ decrease, we investigated whether or not a cellfree extract of $P$. ambigua G-1 was able to decrease the $\mathrm{Cr}^{6+}$ content. The reaction mixture $(2.0 \mathrm{ml})$ contained $200 \mu \mathrm{M} \quad \mathrm{Cr}^{6+}$ and $100 \mathrm{mg}$ (as protein) of a cell-free extract in $50 \mathrm{~mm}$ phosphate buffer ( $\mathrm{pH} 7.0)$. The reaction was stopped by adding $0.5 \mathrm{ml}$ of $20 \%$ trichloroacetic acid. The mixture was centrifuged to remove denatured proteins. The total $\mathrm{Cr}$ and $\mathrm{Cr}^{6+}$ in the supernatant were determined. As shown in Table I, after $30 \mathrm{~min}$ incubation at $50^{\circ} \mathrm{C}, \mathrm{Cr}^{6+}$ was decreased to $120 \mu \mathrm{M}$, but no change in the total amount of $\mathrm{Cr}$ had occurred. A cell-free extract heated at $100^{\circ} \mathrm{C}$ for $5 \mathrm{~min}$ did not cause a decrease in $\mathrm{Cr}^{6+}$. These results suggest that the cell-free extract of $P$. ambigua G-1 was able to transform $\mathrm{Cr}^{6+}$ to another form as to valency. $\mathrm{The}^{\mathrm{Cr}^{6+}}$ decreasing activity was located in a soluble fraction of ultracentrifugation $(105,000 \times g, 2 \mathrm{hr})$. There was no $\mathrm{Cr}^{6+}$ decreasing activity in the insoluble fraction. After $\mathrm{Cr}^{6+}$ had completely disappeared due to the action of $\mathrm{Cr}^{6+}$ decreasing activity in a cell-free extract, the reaction mixture was treated with ammonium persulfate in the presence of sodium hydroxide. $\mathrm{Cr}^{6+}$ appeared again in the oxidized reaction mixture, which indicated that the disappearance of $\mathrm{Cr}^{6+}$ was due to its reduction to a form of lower valency.

\section{Requirement of $\mathrm{NADH}$ for $\mathrm{Cr}^{6+}$ reduction}

As shown in Table II, the $\mathrm{Cr}^{6+}$ reducing activity of a cell-free extract of $P$. ambigua G-1 was found to be inactivated on dialysis. However, the activity was restored to some extent by the addition of a concentrated diffusate to the reaction mixture. This suggests that the $\mathrm{Cr}^{6+}$ reducing enzyme requires cofactor(s) for the reaction. So, we examined whether or not redox cofactors can restore the enzyme activity. Table II shows that NADH was required for the reduction of $\mathrm{Cr}^{6+}$ by the reducing enzyme. NADPH did not cause any restoration of the enzyme activity. 
TABLE II. REQUIREMENT OF NADH FOR THE REDUCTION OF $\mathrm{Cr}^{6+}$

A cell-free extract was dialyzed overnight against distilled water at $4{ }^{\circ} \mathrm{C}$. The diffusate was concentrated in vacuo under $40^{\circ} \mathrm{C}$. The activity of the $\mathrm{Cr}^{6+}$ reducing enzyme in the cell-free extract before dialysis was taken as $100 \%$.

\begin{tabular}{lc}
\hline Component & $\begin{array}{c}\mathrm{Cr}^{6+} \text { reducing } \\
\text { activity }(\%)\end{array}$ \\
\hline Cell-free extract & 100 \\
Dialyzate & 17 \\
Diffusate & 0 \\
Dialyzate plus diffusate & 70 \\
Dialyzate plus NADH & 66 \\
Dialyzate plus NADPH & 18 \\
\hline
\end{tabular}

TABle III. Equivalent Formation OF $\mathrm{Cr}^{3+}$ TO $\mathrm{Cr}^{6+}$ Reduction

After incubation, the reaction mixture $(2 \mathrm{ml})$ was acidified by the addition of $2 \mathrm{ml}$ of $2 \mathrm{~N} \mathrm{HCl}$. Separation of $\mathrm{Cr}^{6+}$ from $\mathrm{Cr}^{3+}$ was performed by the tributylphosphate extraction method described by Hikime and Yoshida: ${ }^{10}$ $\mathrm{Cr}^{6+}$ was completely extracted with tributylphosphate. The aqueous phase only contains $\mathrm{Cr}^{3+}$.

\begin{tabular}{cccc}
\hline $\begin{array}{c}\text { Reaction } \\
\text { time (min) }\end{array}$ & $\begin{array}{c}\mathrm{Cr}^{6+} \\
(\mu \mathrm{M})\end{array}$ & $\begin{array}{c}\mathrm{Cr}^{3+} \\
(\mu \mathrm{M})\end{array}$ & $\begin{array}{c}\text { Total } \\
\mathrm{Cr}(\mu \mathrm{M})\end{array}$ \\
\hline 0 & 200 & 0 & 200 \\
30 & 122 & 71 & 193 \\
60 & 103 & 92 & 195 \\
\hline
\end{tabular}

\section{Reduced products on $\mathrm{Cr}^{6+}$ reduction}

Hikime and Yoshida ${ }^{10)}$ reported that $\mathrm{Cr}^{6+}$ was easily extracted with tributylphosphate, but that $\mathrm{Cr}^{3+}$ was not. The reduced product of $\mathrm{Cr}^{6+}$ with the $\mathrm{Cr}^{6+}$ reducing enzyme could not be extracted with tributylphosphate. Since the naturally occurring stable forms as to valency of $\mathrm{Cr}$ are the trivalent and hexavalent forms, this suggests that the reduced product of $\mathrm{Cr}^{6+}$ may be the trivalent form of $\mathrm{Cr}\left(\mathrm{Cr}^{3+}\right)$. The time course of $\mathrm{Cr}^{6+}$ reduction by the enzyme is shown in Table III. The decrease in $\mathrm{Cr}^{6+}$ corresponded with the increase in $\mathrm{Cr}^{3+}$. To elucidate whether or not the oxidation of NADH to NAD occurs during the $\mathrm{Cr}^{6}$ reduction, the following experiments were performed. On the addition of the reducing
TABle IV. $\mathrm{Cr}^{6+}$ Reducing Enzymes of $\mathrm{Cr}^{6+}$ Sensitive Mutants Derived FROM P. ambigua G-1

The cells were cultivated aerobically at $30^{\circ} \mathrm{C}$ in nutrient broth. The details are given under MATERIALS AND METHODS.

\begin{tabular}{lc}
\hline Strain & $\begin{array}{c}\text { Specific activity } \\
\text { (units/mg protein) }\end{array}$ \\
\hline $\begin{array}{l}\text { P. ambigua } \text { G-1 } \\
\mathrm{Cr}^{6+} \text { sensitive mutant }\end{array}$ & 0.086 \\
S-1 & \\
S-2 & 0.023 \\
S-3 & 0.027 \\
S-4 & 0.007 \\
S-5 & 0.020 \\
S-6 & 0.016 \\
S-7 & 0.020 \\
\hline
\end{tabular}

enzyme, the absorbance at $340 \mathrm{~nm}$ rapidly decreased. After the enzyme had been completely inactivated by treatment at $80^{\circ} \mathrm{C}$ for 5 min, NAD-linked yeast alcohol dehydrogenase (5.2 units) and an excess amount of ethanol were added. The addition of ethanol increased the absorbance to about $70 \%$ of the initial level. These results indicate that the reduction of $\mathrm{Cr}^{6+}$ by the reducing enzyme was accompanied by the oxidation of $\mathrm{NADH}$ to NAD.

$\mathrm{Cr}^{6+}$ reducing enzyme activities of $\mathrm{Cr}^{6+}$ sensitive mutants derived from $P$. ambigua $G-1$

The $\mathrm{Cr}^{6+}$ sensitive mutants were derived from $P$. ambigua G-1 by treatment with $N$ methyl- $N^{\prime}$-nitro- $N$-nitrosoguanidine, as described previously. ${ }^{7)}$ Table IV shows the activities of the reducing enzymes of several $\mathrm{Cr}^{6+}$ sensitive mutants. The specific activities of the reducing enzymes in cell-free extracts of all the sensitive mutants tested showed decreases to one fourth to one tenth of that of the parent strain.

\section{Effect of glucose}

Shimada and Matsushima ${ }^{12)}$ showed that a $\mathrm{Cr}^{6+}$ tolerant bacterium, Pseudomonas K-21, was capable of reducing $\mathrm{Cr}^{6+}$ in the presence of glucose. So, we examined the effect of 
glucose on the induction of the $\mathrm{Cr}^{6+}$ reducing enzyme in P. ambigua G-1. Glucose was added to the nutrient broth at a concentration of $0.5 \%$. However, glucose did not affect the induction of the enzyme. On the other hand, glucose $(20 \mathrm{~mm})$ completely protected the enzyme from inactivation on dialysis. Fructose, galactose and sucrose did not show any protective effect at up to $50 \mathrm{~mm}$.

\section{DISCUSSION}

In a previous paper, ${ }^{7)}$ we reported that $\mathrm{Cr}^{6+}$ tolerant $P$. ambigua $\mathrm{G}-1$ exhibited a membrane barrier as to the penetration of $\mathrm{Cr}^{6+}$ into the cells, as a mechanism of $\mathrm{Cr}^{6+}$ tolerance in the bacterium. However, since some $\mathrm{Cr}$ accumulation in $P$. ambigua $\mathrm{G}-1$ was observed when cells were cultivated in nutrient broth containing $\mathrm{Cr}^{6+}$, some of the $\mathrm{Cr}^{6+}$ penetrated into the cells through the membrane barrier. This implied that $P$. ambigua G1 might have a mechanism for the detoxification of $\mathrm{Cr}^{6+}$. In this study, we demonstrated that $P$. ambigua $\mathrm{G}-1$ could reduce $\mathrm{Cr}^{6+}$ to $\mathrm{Cr}^{3+}$, i.e., it has a $\mathrm{Cr}^{6+}$ reducing enzyme for $\mathrm{Cr}^{6+}$ reduction. This reduction may be a second mechanism of $\mathrm{Cr}^{6+}$ tolerance in $P$. ambigua G-1.

The reducing enzyme of $P$. ambigua G-1 requires $\mathrm{NADH}$ as a hyrogen donor, but not NADPH, in the reduction of $\mathrm{Cr}^{6+}$. Gruber and Jennette ${ }^{11)}$ showed that the incubation of $\mathrm{Cr}^{6+}$ with rat liver microsomes in the presence of NADPH resulted in reduction of the $\mathrm{Cr}^{6+}$, suggesting that the $\mathrm{Cr}^{6+}$ reducing enzyme in rat liver microsomes required $\mathrm{NADPH}$ as a hydrogen donor.

Shimada and Matsushima ${ }^{12)}$ pointed out that glucose might play an important part in the $\mathrm{Cr}^{6+}$ reduction by $\mathrm{Cr}^{6+}$ tolerant Pseudomonas K-21, which was isolated from Cr sludge. On the other hand, P. ambigua G-1 did not require glucose for the reduction of $\mathrm{Cr}^{6+}$. However, glucose protected the $\mathrm{Cr}^{6+}$ reducing enzyme from inactivation on dialysis. Thus, glucose acted as a stabilizer for the reducing enzyme. At present, we have no idea as to the mechanism of the protection.

Although $\mathrm{Cr}^{3+}$ and NAD were found in the reaction mixture as products after reduction of $\mathrm{Cr}^{6+}$ by the reducing enzyme, the detailed mechanism of the reaction was not clarified. We are now attempting the purification and characterization of the $\mathrm{Cr}^{6+}$ reducing enzyme of $P$. ambigua $\mathrm{G}-1$.

\section{REFERENCES}

1) J. D. Efstathiou and L. L. Mckay, J. Bacteriol., 130, 257 (1977).

2) A. O. Summers and G. A. Jacoby, Antimicrob. Agents Chemother., 13, 637 (1978).

3) G. W. Luli, J. W. Talngi, W. R. Strohl and R. M. Pfister, Appl. Environ. Microbiol., 46, 846 (1983).

4) L. H. Bopp, A. M. Chakrabarty and H. L. Ehrlich, J. Bacteriol., 155, 1105 (1983).

5) H. Horitsu, H. Nishida, H. Kato and M. Tomoyeda, Agric. Biol. Chem., 42, 2037 (1978).

6) R. H. Smillie, K. Hunter and M. Loutit, Water Res., 15, 1351 (1981).

7) H. Horitsu, S. Futo, K. Ozawa and K. Kawai, Agric. Biol. Chem., 47, 2907 (1983).

8) Japanese Industrial Standards Committee, Testing Methods for Industrial Water (1969).

9) O. Folin and V. Ciocalteu, J. Biol. Chem., 73, 627 (1927)

10) S. Hikime and H. Yoshida, Japan Analyst, 8, 756 (1959).

11) J. E. Gruber and K. W. Jennette, Biochem. Biophys. Res. Commun., 82, 700 (1978).

12) K. Shimada and K. Matsushima, Mie Daigaku Nougakubu Gakujyutsu Houkoku, 67, 101 (1983). 